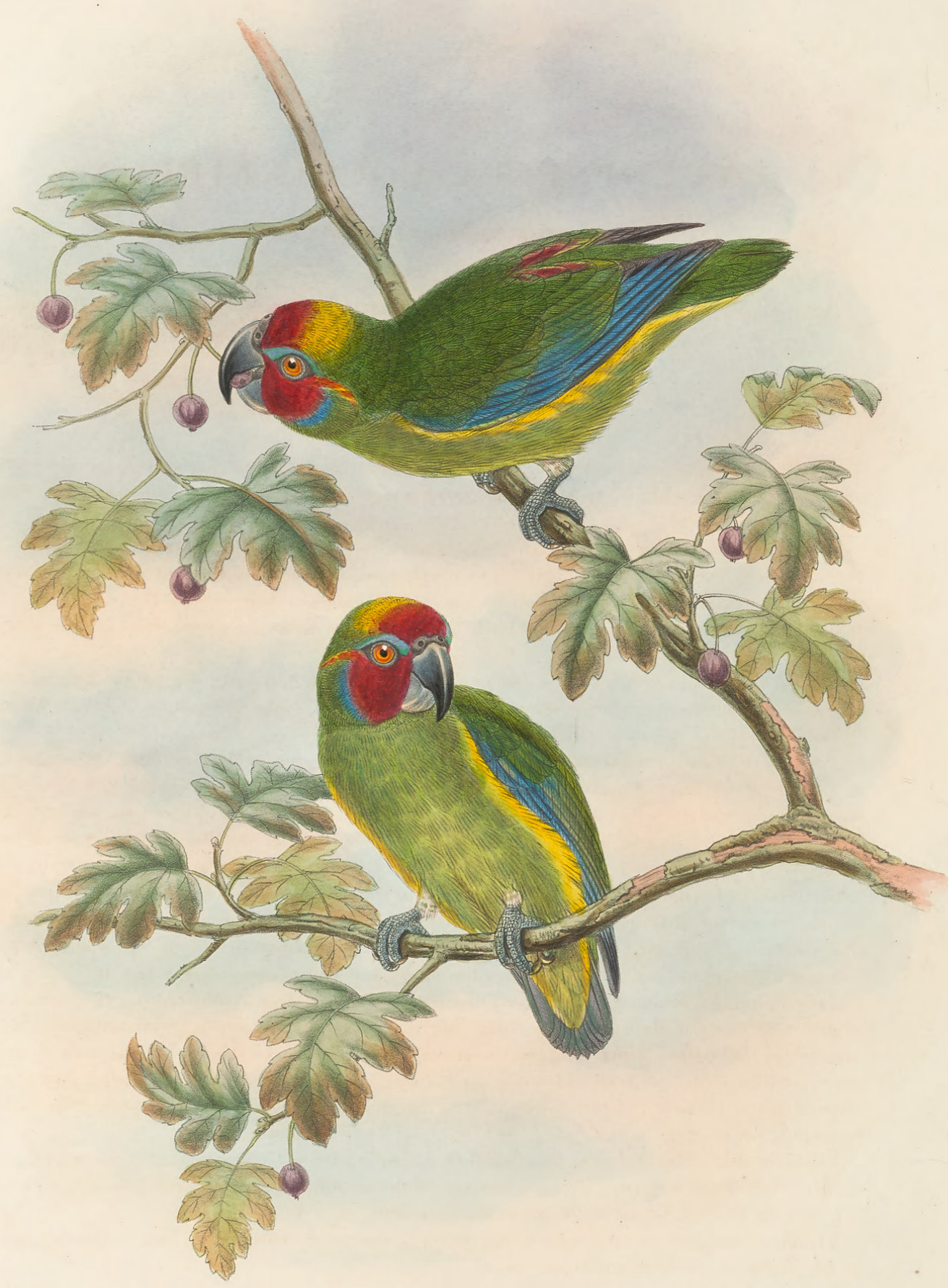




\title{
CYCLOPSITTA COCCINEIFRONS.
}

\author{
Astrolabe-Mountain Perroquet.
} Cyclopsittacus coccineifrons, Sharpe, Journ. Linn. Soc., Zool. xvi. pp. 318, 426 (1882).-Salvad. Ann. Mus. Civic.
Genov. xviii. p. 418 (1882).-Id. Orn. Papuasia e delle Molucche, iii. p. 516 (1882).

THis species was discovered by Mr. Goldie in the Morocco district of the Astrolabe Mountains in Sontheastern New Guinea. Mr. H. O. Forbes has recently met with it in the Sogeri district on the same range of mountains.

We separated the present species from $C$. diophthalmus on account of the darker colour of the red on the crown, but now that we have had an opportunity of examining a second specimen, and that a male bird, we do not find that this distinction is upheld, but the species is nevertheless different from $C$. diophthalmus. It may in fact be recognized by the greater breadth of the yellow band across the crown, which is little more than a narrow line in the last-named species.

Neither Mr. Goldie nor Mr. Forbes have giren any information respecting the habits of this pretty little Perroquet, but the former gentleman states that it is called 'Ciguri' by the natives of the Astrolabe Mountains. The following is a description of the sexes of this species :-

Adult female. General colour above grass-green; lesser wing-coverts like the back, becoming a little brighter on the median and greater coverts, the outermost of which are slightly washed with blue; bastardwing and primary-coverts deep blue; quills black, the primaries externally deep blue; the secondaries green like the back; the innermost marked with scarlet on the inner web, as also the innermost greater coverts; tail-feathers darker green than the back, washed with blue near the base and on the inner web; a broad band across the forehead and sinciput, deep scarlet or dull crimson, succeeded by a well-defined band of yellow, the occiput and nape and hind neck a little more yellowish green than the back; lores crimson, as also a streak below the eye; above the fore part of the eye a broad streak or longitudinal spot of greenish turquoise; ear-coverts and cheeks pale drab-brown, washed with greenish blue below, and with a narrow line of purplish blue behind the ear-coverts; under surface of body light emerald-green, with a broad streak of golden yellow down the sides of the body; thighs and under tail-coverts light emerald-green, the long ones edged with yellow; under wing-coverts emerald-green, those near the edge of the wing deep bluish green ; axillaries emerald-green with a darker green centre; lower coverts and quills below dusky blackish, crossed with a double bar of pale yellow. Total length $5 \cdot 6$ inches, culmen $0 \cdot 55$, wing $3 \cdot 65$, tail $1 \cdot 55$, tarsus $0 \cdot 3$.

The adult male differs from the type, which is evidently a female, in having the cheeks and sides of face scarlet: "bill bluish carneous, black on the tips of the mandibles; legs and feet pale blue; iris orangered” (H. O. Forbes). Total length $5 \cdot 5$ inches, wing $3 \cdot 25$, tail $1 \cdot 45$, tarsus $0 \cdot 35$.

The Plate represents an adult male in two positions, the figures being drawn from a specimen procured by Mr. Forbes in the Astrolabe Mountains. 


\section{$2 \mathrm{BHL}$ Biodiversity Heritage Library}

Gould, John and Sharpe, Richard Bowdler. 1887. "Cyclopsitta coccineifrons, Astrolabe-Mountain Perroquet [PI. 8]." The birds of New Guinea and the adjacent Papuan islands : including many new species recently discovered in Australia 5(XXIII), -. https://doi.org/10.5962/p.322852.

View This Item Online: https://www.biodiversitylibrary.org/item/230441

DOI: https://doi.org/10.5962/p.322852

Permalink: https://www.biodiversitylibrary.org/partpdf/322852

\section{Holding Institution}

Smithsonian Libraries

\section{Sponsored by}

Biodiversity Heritage Library

\section{Copyright \& Reuse}

Copyright Status: Public domain. The BHL considers that this work is no longer under copyright protection.

This document was created from content at the Biodiversity Heritage Library, the world's largest open access digital library for biodiversity literature and archives. Visit BHL at https://www.biodiversitylibrary.org. 